\title{
KINERJA ANGGOTA DEWAN PERWAKILAN RAKYAT DAERAH KABUPATEN BENGKULU TENGAH DALAM MENJALANKAN FUNGSI PENGAWASAN PERATURAN DAERAH
}

\author{
Oleh : \\ HARDI, HARIUS EKO SAPUTRA, ASNAWATI \\ Program Studi Administrasi Publik Fakultas Ilmu-Ilmu Sosial \\ Universitas Dehasen Bengkulu
}

\begin{abstract}
The purpose of this study is to determine the performance of members of the Regional House of Representatives of Central Bengkulu Regency in carrying out the supervisory function of the Regional Regulations. This research was used descriptive method with qualitative approach. The data collectionwere used interview techniques, observation, and documentation. The result of the research shows that the performance of members of DPRD of Central Bengkulu Regency in carrying out the supervisory function of the regional Regulation through the established mechanism that is through work meeting, go down to the field area for checking the monitoring objects, and synchronize the planning documents and the implementation documents. Supervision conducted by members of DPRD of Central Bengkulu Regency implemented after the exit policy. The form of supervision of the Regional Regulation conducted by members of DPRD of Central Bengkulu Regency is directly monitoring the spaciousness, listening to community input, and hearing together to carry out the supervisory function of the existing Regional Regulation. Obstacles faced by DPRD members in carrying out supervisory functions are topography of Central Bengkulu that is difficult to reach, technical constraints, lack of transparency, and openness of Local Government.
\end{abstract}

Keywords: performance, DPRD, supervision function, regional regulation

\section{PENDAHULUAN}

Dengan adanya Otonomi dan desentralisasi kekuasaan dari pusat kepada daerah maka pemerintahan daerah serta masyarakat setempat juga berpengaruh sekali terhadap lajunya perkembangan daerah dan juga jalannya pemerintahan di Daerah tersebut. Seperti yang tertuang dalam UU NO. 23 Tahun 2014 tentang pemerintah daerah.

Undang-Undang tersebut telah dilimpahkan kekuasaan baik secara politik maupun secara administratif kepada daerah untuk menyelenggarakan kewenangan sesuai dengan prakarsa dan inisiatif masyarakat didaerah selain 6 (enam) kewenangan yang masih kewenangan pemerintah pusat antara lain politik luar negeri, moneter dan fiscal nasional, agama, pertahanan, keamanan, dan yudisial. Pelimpahan kewenangan itulah yang kita namakan dengan " Otonomi Daerah" pelimpahan secara otomatis juga memindahkan fokus politik ke daerah karena pusat kekuasaan tidak hanya dimonopoli oleh pemerintah pusat seperti di era sentralisasi namun telah terdistribusi ke daerah. Pelimpahan 
kewenangan itu disertai pula dengan pemberian kekuasaan yang lebih besar bagi Dewan Perwakilan Rakyat Daerah (DPRD) dalam menjalankan fungsi Legislasi, Budgeting, dan Controling karena diharapkan dengan "Otonomi Daerah" Dewan Perwakilan Rakyat Daerah (DPRD) mampu meningkatkan pembuatan peraturan daerah yang sesuai dengan kebutuhan hukum masyarakat di daerah.

Dewan Perwakilan Rakyat Daerah (DPRD) Kabupaten/Kota merupakan lembaga perwakilan rakyat daerah yang berkedudukan sebagai lembaga pemerintah Daerah Kabupaten/Kota. Yang memiliki fungsi yaitu legislasi, anggaran, dan pengawasan. Funggsi legislasi DPRD yakni menyusun perundang-undangan dalam bentuk peraturan Daerah, fungsi anggaran DPRD yakni memberikan persetujuan terhadap rencanaa anggaran daerah yang mencakup rencana pendapatan, belanja, dan pembiayaan, fungsi pengawasan DPRD yakni memastikan berjalannya perundangundangan yang ada dan optimalnya kinerja eksekutif. Berdasarkan ketentuan UndangUndang No.23/2014 tentang pemerintah daerah, DPRD Kabupaten/Kota terdiri atas partai politik peserta pemilihan umum yang dipilih berdasarkan hasil pemilihan umum. Kedukdukan DPRD Kabupaten/Kota adalah sebagai lembaga perwakilan rakyat daerah yang berkedudukan sebagai unsur penyelengara pemerintah daerah Kabupaten/Kota.

Dalam pasal 154 ayat 1 DPRD Kabupaten/Kota mempunyai tugas dan wewenang: (a). Membentuk peraturan daerah yang dibahas dengan Bupati/Walikota dan mendapat persetujuan bersama, (b). Menetapkan APBD Kabupaten/Kota bersama-sama dengan Bupati?Walikota, (c). Melaksanakan pengawasan terhadap pelaksanaan peraturan daerah dan peraturan perundangundangan lainnya, keputusan bupati/walikota, APBD, kebijakan pemerintah daerah dalam melaksanakan program pembangunan daerah. Dan kerjasama internasional di daerah, (d). Mengusulkan pengangkatan dan pemberitahuan bupati/walikota atau walikota/ wakil walikota kepada Menteri Dalam Negeri melalui Gubernur, (e). Memberikan pendapat dan pertimbangan kepada pemerintah daerah Kabupaten/Kota terhadap rencana perjanjian internasional yang menyangkut kepentingan daerah, (f). Meminta laporan keterangan pertanggungjawaban Bupati/ Walikota dalam pelaksanaan tugas desentralisasi.

Menurut UU No. 23 Tahun 2014 tentang pembentukan peraturan perundang-undangan menyatakan bahwa peraturan daerah Kabupaten/Kota adalah peraturan perundang-undangan yang dibentuk oleh Dewan Perwakilan Rakyat Daerah Kabupaten/Kota dengan persetujuan bersama Bupati/Walilota. Dalam penyusunan dan pembentukan perundang-undangan maka DPRD Kabupaten/Kota itu memiliki PERDA Hak Inisiatif DPRD dan PERDA usulan Eksekutif tentang APBD.

Hak inisiatif DPRD merupakan hak untuk mengajukan raperda merupakan salah satu hak yang dimiliki oleh DPRD untuk melaksanakan fungsinya dalam pembentukan PERDA, karena kekuasaan legislasi merupakan inti kedaulatan rakyat maka semua badan perwakilan rakyat (DPR RI, DPRD Provinsi, dan DPRD Kabupaten/Kota) mempunyai hak inisiatif. Hak inisiatif DPRD Kabupaten/Kota dalam Undang-Undang No 23 Tahun 2014 Tentang Pemerintah Daerah: a). Pasal 149 ayat (1) huruf a, DPRD Kabupaten/Kota mempunyai fungsi pembentukan PERDA Kabupaten/Kota. b). Pasal 150, menjelaskan bahwa fungsi pembentukan PERDA Kabupaten/Kota sebagaimana yang dimaksud dalam pasal 149 ayat (1) huruf a dilaksanakan dengan cara: mengajukan usulan rancangan peraturan daerah (PERDA) Kabupaten/Kota, c). Pasal 160 anggota DPRD Kabupaten/Kota mempunyai hak: mengajukan Rancangan 
Peraturan Daerah (PERDA)

Kabupaten/Kota.

PERDA usulan Eksekutif tentang APBD merupakan rencana kerja pemerintah daerah yang diperhitungkan dalam uang dengan memperkirakan penerima dan pengeluaran uang dalam periode tertentu yaitu satu tahun. Rancangan pendapatan belanja daerah (APBD) yang telah disusun oleh pemerintah daerah dibahas dan ditetapkan oleh DPRD menjadi peraturan daerah, dan peraturan yang dilaksanakan oleh pemerintah daerah berada dibawah pengawasan DPRD. PERDA usulan Eksekutif tentang APBD Kabupaten/Kota dalam Undang-Undang No 23 Tahun 2014 Tentang Pemerintah Daerah: a). Pasal 152 ayat (1 dan 2) fungsi anggaran sebagaimana dimaksud pasal 149 ayat (1) huruf $b$ diwujudkan dalam bentuk pembahasan untuk persetujuan bersama terhadap rancangan PERDA Kabupaten/Kota tentang APBD Kabupaten/Kota yang diajukan oleh Bupati/Walikota, fungsi anggaran sebagaimana dimaksud ayat (1) dilaksanakan dengan cara: 1. Membahas rancangan PERDA Kabupaten/Kota tentang APBD Kabupaten/kota, 2. Membahas rancangan PERDA Kabupaten/Kota tentang perubahan APBD Kabupaten/Kota, dan 3. Membahas rancangan PERDA Kabupaten/Kota tentang pertanggungjawaban pelaksanaan APBD Kabupaten/Kota, b). Pasal 154 ayat (1) huruf b DPRD Kabupaten/Kota mempunyai tugas dan wewenang: membahas dan memberikan persetujuan rancangan PERDA mengenai APBD Kabupaten/kota yang diajukan oleh Bupati/Walikota (Undang-Undang No. 23 Tahun 2014).

Dewan perwakilan rakyat Kabupaten Bengkulu Tengah terbentuk dari pemekaran Kabupaten yaitu Kabupaten Bengkulu Utara, telah mengalami berbagai perubahan, baik struktur maupun komposisi anggota DPRD. Anggota DPRD Kabupaten Bengkulu Tengah untuk periode 2014-2019 terdiri dari 25 anggota DPRD yaitu 3 pimpinan DPRD dan 22 anggota yang terpilih melalui pemilihan umum, dan merupakan wakil dari semua wilayah pemilihan di Kabupaten Bengkulu Tengah dan anggota Partai Politik yang berkedudukan di wilayah pemerintahan Kabupaten Bengkulu Tengah. Salah satu tugas dan fungsi DPRD yaitu membuat peraturan Daerah salah satu peraturan perundang-undangan yang berlaku dalam sistem ketatanegaraan Indonesia. Peraturan Daerah merupakan peraturan yangg bersifat lokal yang berlaku di daerah tempat produk hukum tersebut dibentuk yakni daerah Provinsi dan daerah Kabupaten dan Kota.

Beberapa peraturan daerah yang dikeluarkan Dewan Perwakilan Rakyat Daerah Kabupaten Bengkulu Tengah periode 2014-2017: 1. Raperda perubahan kedua atas peraturan daerah Kabupaten Bengkulu Tengah No 1 Tahun 2012 tentang retribusi jasa umum, 2. Raperda perangkat Desa, 3. Raperda lalulintas angkutan jalan, sungai, danau, dan penyembrangan, 4 . Raperda penangulangan bencana alam, 5. Raperda pertanggungjawaban pelaksanaan APBD Tahun anggaran 2015, 6. Raperda APBD perubahan Tahun anggaran 2016, 7. Raperda izin usaha kontruksi. 8. Raperda kesejahteraan usia lanjut, 9. Raperda penyelenggaraan zakat, 10. Raperda pembentukan Kecamatan Gunung Bungkuk, 11. Raperda perlindungan lahan pertanian taman pangan berkelanjutan, 12 . Raperda usaha mikro kecil dan menengah, 13. Raperda pembuatan jalan umum dan jalan khusus angkutan batu bara.

Namun demikian masih harus dikaji secara mendalam, secara ilmiah, dan mengikuti aturan empiris, mengingat bahwa kinerja anggota Dewan Perwakilan Rakyat Daerah Kabupaten Bengkulu Tengah dalam fungsi legislasi, anggaran dan pengawasan merupakan salah satu faktor penting dalam mempengaruhi jalannya pelaksanaan tanggung jawab sebagai pemerintah daerah. Dewan 
Perwakilan Rakyat Daerah sebagai lembaga yang mengawasi peraturan daerah dan keputusan pemerintah daerah dimaksudkan bahwa Dewan Perwakilan Rakyat Daerah melakukan pengawasan terhadap peraturan daerah serta peraturan pemerintah daerah. Setelah peraturan daerah itu dibuat bersama antara Dewan Perwakilan Rakyat Daerah dan Bupati, maka Dewan Perwakilan Rakyay Daerah maih perlu mengawasi atas beralakunya peraturan daerah tersebut karena pengawasan adalah merupakan salah satu fungsi Dewan Perwakilan Rakyat Daerah dalam kesinambungan pemerintah daerah, sehingga peraturan daerah dapat berjalan dengan baik.

Fungsi Dewan Perwakilan Rakyat Daerah (DPRD) salah satu yang penting adalah melaksanakan fungsi pengawasan didalam proses Pemerintahan di Daerah, Dewan Perwakilan Rakyat Daerah (DPRD) dapat melakukan kontrol terhadap Pemerintah Daerah, agar dalam menjalankan tugasnya Pemerintah Daerah tidak melakukan penyimpanganpenyimpangan dari garis yang sudah ada. Fungsi pengawasan ini merupakan bentuk tindakan untuk mengawasi kebijakan Pemerintah.(Sunarto, 2004: 38)

Pengawasan yang dilakukan mengharapkan agar kebijakan yang dikeluarkan tidak menyimpang dari garis yang telah ditetapkan dan Pemerintah Daerah tidak melakukan Penyimpanganpenyimpangan.

Dari uraian diatas dapat dilihat bahwa kebijakan yang dimiliki Bupati Bengkulu Tengah bisa memunculkan persoalan, oleh karenanya kontrol yang dilakukan DPRD Kabupaten Bengkulu Tengah Sangat dibutuhkan.oleh karena itu penulis tertarik mengangkat judul "Kinerja Anggota Dewan Perwakilan Rakyat Daerah (DPRD) Kabupaten Bengkulu Tengah Dalam Menjalankan Fungsi Pengawasan Peraturan Daerah".

\section{METODE PENELITIAN}

Moleong (2004: 4) Penelitian ini memggunakan metode deskriptif dengan pendekatan kualitatif. Penelitian kualitatif adalah prosedur penelitian yang menghasilkan data deskriftif berupa katakata atau lisan dari orang-orang dan prilaku yang dapat diamati.Penelitian desskriptif dimaksudkan untuk memberikan gambaran secara sistematis tentang situasi, permasalahan, fenomena, layanan atau program, ataupun memberikan informasi kondisi kehidupan suatu masyarakat serta situasi-situasi, sikap, pendangan, proses yang sedang berlangsung pengaruh dari suatu fenomena, pengukuran yang cermat tentang fenomena dalam masyarakat.

\section{Informan Penelitian}

Dalam penelitian ini, informan merupakan sumber data penelitian tersebut. Dalam penelitian kualitatif, penentuan informan yang terpenting adalah bagai mana menentukan key informan (informasi kunci) atau situasi sosial tertentu yang sarat informasi sesuai dengan fokus penelitian. Penelitian ini dalam penentuan

Informannya menggunakan teknik sampling purposive . penentuan sumber data secara pusposive ditentukan dengan menyesuaikan pada tujuan penelitian atau tujuan tertentu, penentuan informan dalam penelitian ini dilakukan saat peneliti mulai memasuki lapangan dan selama penelitian peneliti memilih orang-orang tertentu yang mempertimbangkan akan memberikan data yang diperlukan sesuai dengan fokus penelitian.

Menurut Spradlay: 'situasi sosial untuk sampel awal sangat disarankan suatu situasi sosial yang didalamnya menjadi semacam muara dari banyak domain lainnya' (dalam Sugoyono, 2007: 221). Selanjutnya dinyatakan bahwa sampel sebagai sumber data atau informan sebaiknya memenuhi kriteria sebagai berikut: 
1. Mereka yang menguasai atau memahami suatu melalui proses akulturasi yang tengah diteliti.

2. Mereka tergolong masih berkecimpung atau terlibat dalam kegiatan yang tengah diteliti.

3. Mereka yang mempunyai kesempatan wakyu yang memadai untuk diminta informasinya.

4. Mereka yang mulanya cukup asing dengan peneliti sehingga lebih menggairahkan untuk dijadikan guru atau narasumber.

\section{Jenis Data}

\section{Data Primer}

Data primer adalah data yang diperoleh langsung adari hasil wawancara yang diperoleh dari nara sumber atau informan terpilih pada lokasi penelitian yang dianggap berpotensi dalam memberikan informasi yang relevan dan sebenarnya dilapangan.

\section{Data Sekunder}

Data sekunder adalah data pendukung data primer dari literatur dan dokumen serta data yang isinya menyangkut tentang masalah yang bersangkutan dengan penelitian yang dikaji oleh peneliti, meliputi profil organisasi, struktur organisasi dan studi dokumentasi yang diperoleh dari DPRD Kabupaten Bengkulu Tengah. Serta rujukan buku, koran, dan internet yang dapat menjadi referensi bagi penelitian.

\section{Teknik Pengumpulan Data}

Teknik pengumpulan data menurut Sugiono (2012: 224) merupakan langkah yang paling strategis dalam penelitian, karena tujuan utama dari penelitian adalah mendapatkan data. Tanpa mengetahui teknik pengumpulan data, maka peneliti tidak akan mendapatkan data yang memenuhi standar data yang ditetapkan. Untuk memperoleh data penelitian yang lengkap dan dapat dipertanggungjawabkan kebenarannya, maka teknik pengumpulan data yang digunakan peneliti dalam mengambil beberapa data guna mendapatkan informasi ialah sebagai berikut:

\section{Wawancara (interview)}

Dalam Satori dan Komariah (2010: 130) wawancara adalah suatu teknik pengumpulan data untuk mendapatkan informasi yang digali dari sumber data langsung melalui percakapan atau tanya jawab. Wawancara dalam penelitian ini sifatnya mendalam kerena ingin mengeksplorasi informasi secara jelas dari informan yang telah ditemukan.

\section{Observasi}

Nasution (dalam maloeng, 2004: 64) menyatakan bahwa, observasi adalah metode pengumpulan data yang digunakan untuk menghimpun data penelitian melalui pengamatan dan pengindraan. Para ilmuan hanya dapat bekerja berdasarkan data, yaitu fakta mengenai kejadian dilapangan yang nyata yang diperoleh melalui observasi.

\section{Dokumentasi}

Guba dan Linco (dalam moloeng, 2004: 206). Dokementasi adalah salah satu metode pengumpulan data dengan melihat atau menganalisis dokumendokumen yang dibuat oleh subjek sendiri atau orang lain tentang subjek. Dokumen merupakan catatan peristiwa yang sudah berlalu. Dokumen bisa berbentuk tulisan, gambar, atau karyakarya menumental seseorang.

\section{Teknik Analisa Data}

Menurut Bogdan dalam Sugoino (2012: 224), analisis data adalah proses mencari dan menyusun secara sistematis data yang diperoleh dari hasil wawancara, catatan lapangan, dan bahan-bahan yang lain yang telah dikumpulkan kemudian dilakukan penyusunan. Analisis data adalah proses penyederhanaan data dalam bentuk yang lebih muda dibaca dan di interpretasikan, data yang diperoleh kemudian di analisis secara bersamaan dengan proses yang cukup panjang. Data dari hasil wawancara yang diperoleh kemudian dicatat dan dikumpulkan sehingga menjadi sebuah catatan lapangan. 
Dalam penelitian kualitatif, kegiatan analisis data dimulai sejak peneliti melakukan kegiatan pra lapangan sampai dengan selesainya penelitian. Dalam penelitian kualitatif, teknik analisa data yang digunakan diarahkan untuk menjawab rumusan masalah.

Analisis yang digunakan dalam penelitian ini bersifat kualitatif, dengan memasukan data dari informan atau wawancara yang kemudian diananlisis dan ditarik kesimpulan. Sehingga dalam penelitian ini, peneliti menganalisis data mengenai responsivitas, responsibilitas, dan akuntabilitas yang dilakukan oleh anggota DPRD Bengkulu Tengah dalam menyusun produk hukum daerah. Selama dalam prosesnya, pengumpulan data dilakukan tiga kegiatan penting, diantaranya: reduksi data (data reduction), penyajian data (data display), triangulasi data, kemudian membuat keputusan (keputusan) yang mudah dipahami oleh diri sendiri maupun orang lain.

\section{Reduksi Data (Data Reduction)}

Reduksi data ialah proses pemilihan, pemusaran penelitian pada penyederhanaan, serta transformasi data kasar yang muncul dari catatan-catatan yang tertulis di lapangan, reduksi data merupakan suatu bentuk analisis yang menajam, menggolongkan, mengarahkan, membuang yang tidak perlu, dan mengorganisasikan data dengan cara sedemikian rupa sehingga dapat ditarik kesimpulan. Reduksi data dallam penelitian dilakukan pada data hasil wawancara, dalam hal ini penulis memilih kata-kata yang dapat digunakan untuk melakukan pembahasan. Peneliti mengumpulkan data mengenai resposivitas, responsibilitas, dan akuntabilitas yang dilakukan oleh anggota DPRD Kabupaten Bengkulu Tengah ditinjau dari aspek legislasi dengan melihat kinerja abggota DPRD Bengkulu Tengah.

\section{Penyajian Data (Data Display)}

Penyajian data ialah peneliti menampilkan sekumpulan informasi tersusun berdasarkan data yang didapat secara menyeluruh yang diperoleh dari lokasi hasil penelitian. Penyajian data yang disusun secara singkat, jelas, dan terperinci serta menyeluruh akan memudahkan dalam memahami gambaran terhadap aspek-aspek yang diteliti baik secara keseluruhan maupun secara persial. Hasil reduksi data disususn dan disajikan dalam bentuk teks narasi- deskriptif.

Peneliti melakukan pengumpulan data yang telah direduksi untuk menggambarkan kejadian yang telah terjadi pada saat di lapangan. Catatancatatan penting dilapangan, kemudian disajikan dalam bentuk teks deskriptif untuk mempermudah pembaca memahami secara praktis. Kegiata lanjutan peneliti pada penyajian data adalah data yang didapat disajikan dalam bentuk tabel dengan tujuan untuk mengabungkan informasi yang tersusun dalam bentuk yang padu.

\section{Triangulasi Data}

Selain menggunakan reduksi data dan penyajian data peneliti juga menggunakan teknik trigulasi sebagai teknik untuk mengecek keabsahan data. Dimana dalam pengertiannya (Moelong, 2004: 330), triangulasi adalah teknik pemeriksaan keabsahan data yang memanfaatkan sesuatu yang lain dalam membandingkan hasil wawancara terhadap objek penelitian, triangulasi dapat dilakukan dengan mengunakan teknik yang berbeda (Nasution, 2003: 115) yaitu wawancara, observasi dan dokumen, triangulasi ini selain digunakan untuk mengecek kebeneran data juga dilakukan untuk memperkaya data. Menurut Nasution, selain itu trigulasi juga dapat berguna untuk menyelidiki validitas peneliti terhadap data, karena itu trigulasi bersifat reflektif. 
Denzin (dalam Moloeng, 2004), membedakan empat macam triangulasi diantaranya dengan memanfaatkan penggunaan sumber, metode, penyidik dan teori. Pada penelitian ini, dari empat macam triangulasi tersebut, peneliti hanya menggunakan teknik pemeriksaan dengan memanfaatkan sumber. Trigulasi dengan sumber artinya membandingkan dan mengecek balik derajat kepercayaan suatu informasi yang diperoleh melalui waktu dan alat yang berbeda dalam penelitian kualitatif. Adapun untuk mencapai kepercayaan itu, maka ditempuh langkah sebagai berikut:

a. Membandingkan data hasil pengamatan dengan data hasil wawancara.

b. Membandingkan apa yang dikatakan orang didepan umum dengan apa yang dikatakan secara pribadi.

c. Membandingkan apa yang dikatakan orang-orang tentang situasi penelitian dengan apa yang dikatakannya sepanjang waktu.

d. Membandingkan keadaan dan perspektif seseorang dengan berbagai pendapat dan pandangan masyarakat dari berbagai kelas.

e. Membandingkan hasil wawancara dengan isi suatu dokumen yang berkaitan.

Triangulasi memiliki arti penting dalam menjembatani riset kualitatif, bahwa pengumpulan data triangulasi melibatkan observasi, wawancara, dan dokumentasi. Penyajian data merupakan kegiatan terpenting yang kedua dalam penelitian kualitatif. Penyajian dana yaitu sebagai sekumpulan informasi yang tersusun memberi kemungkinan adanya penarikan kesimpulan dan pengambilan tidakan.

\section{HASIL PENELITIAN DAN PEMBAHASAN}

Penyelenggaraan Otonomi Daerah adalah mendorong untuk memperdayakan masyarakat, meningkatkan kesejahteraan rakyat, pemetaan, keadilan serta penghormatan kepada budaya lain yang memperhatikan potensi dan keanekaragaman Daerah. Otonomi Daerah juga merupakan perwujudan Demokrasi, karena Daerah otonomi diberi dalam sistem negara kesatuan Republik Indonesia dan membuat keputusan sesuai dengan aspirasi yang berkembang di masyarakat.

Fungsi pengawasan yang dilakukan oleh anggota Dewan Perwakilan Rakyat Daerah (DPRD) Kabupaten Bengkulu Tengah merupakan salah satu fungsi manajemen untuk menjamin pelaksanaan kegiatan sesuai dengan kebijakan dan rencana yang telah ditetapkan serta memastikan tujuan secara efektif dan efisien. Fungsi pengawasan ini bermakna penting baik bagi Pemerintah Daerah maupun pelaksana pengawasan. Bagi Pemerintah Daerah, fungsi pengawasan merupakan suatu mekanisme peringatan dini untuk mengawal pelaksanaan aktivitas untuk mencapai tujuan dan sasaran. Sedangkan bagi pelaksana pengawasan, fungsi pengawasan ini merupakan tugas mulia untuk memberikan telaahan dan saran berupa tindakan perbaikan terhadap kinerja Pemerintah Daerah. Pengawasan juga dilaksanakan berdasarkan indikasi suatu pelaksanaan Pemerintah yang menyimpang sehingga Dewan Perwakilan Rakyat Daerah (DPRD) dapat melakukan pemanggilan terhadap Pemerintah Daerah yang biasanya mengundang dinas terkait yang selanjutnya, dilakukan peninjauan lapangan jika diperlukan.

Dari hasil penelitian, peneliti dapat menyimpulkan bahwa Kinerja Anggota Dewan Perwakilan Rakyat Daerah (DPRD) Kabupaten Bengkulu Tengah Dalam Menjalankan fungsi pengawasan sejauh ini sudah cukup optimal karena dilihat dari Peraturan Daerah (PERDA), Peraturan Bupati, Dan Keputusan DPRD serta rencana kerja Dewan Perwakilan Rakyat Daerah (DPRD) Kabupaten Bengkulu Tengah Tahun 2016. Secara Legislasi sudah dilakukan payung hukum secara peraturan Bupati Belum Semua dilaksanakan. Dewan telah melaksanakan 
tugasnya secara Legislasi tapi secara teknik Dewan tidak bisa ikut campur di dalamnya. Oleh karena itu kalau ada kekurangan Dewan memanggil SKPD terkait dengan SKPD yang berkaitan dengan PERDA itu melalui hering bersama atau memberi masukan, saran, pendapat terhadap dinas SKPD yang ada di Bengkulu Tengah.

\section{PENUTUP}

\section{Kesimpulan}

Berdasarkan hasil penelitian yang dilakukan oleh peneliti terhadap Kinerja Anggota Dewan Perwakilan Rakyat Daerah (DPRD) Kabupaten Bengkulu Tengah Dalam Menjalankan Fungsi Pengawasan Peraturan Daerah dapat disimpulkan:

1. Mekanisme DPRD Kabupaten Bengkulu Tengah dalam melakukan fungsi pengawasan Peraturan Dearah yaitu melalui pertama, melalui rapat kerja. Kedua turun langsung kelapangan untuk mengecek objekobjek pengawasan. Ketiga, sinkronisasi dokumen perencanaan dan dokumen pelaksanaan. Dokumen perencanaan dan dokumen pelaksanaan harus sesuai apabila tidak sesuai maka dewan akan memanggil SKPD dan dinas-dinas terkait untuk memperingatkan dan memperbaiki.

2. Bahwa pengawasan yang dilakukan oleh anggota Dewan perwakilan Rakyat Daerah (DPRD) Kabupaten Bengkulu Tengah dilaksanakan sesudah keluar kebijakan. Melalui pengawasan Dewan, Pemerintah Kabupaten Bengkulu Tengah sebagai pelaksana kebijakan akan terhindar dari berbagai penyimpangan dan penyelewengan, dari hasil pengawasan Dewan akan diambil penyempurnaan memperbaiki pelaksanaan kebijakan.

3. Bentuk pengawasan Peraturan Daerah (PERDA) yang dilakukan oleh Dewan Perwakilan Rakyat Daerah (DPRD) Kabupaten Bengkulu Tengah yaitu memonitoring langsung kelapangan, mendengar masukan dari masyarakat, dan hering bersama untuk melakukan fungsi pengawasan Peraturan Daerah yang ada dilapangan.

4. Kendala yang dihadapi anggota DPRD dalam melakukan fungsi pengawasan yaitu topografi Bengkulu Tengah yang sulit dijangkau, kendala teknis, kurang transparansi dan keterbukaan Pemerintah Daerah. Oleh karena itu,untuk mengatasi kendala tersebut Dewan berkoordinasi dengan pihakpihak terkait untuk melakukan rapat kerja, shering, bermusyawarah, sehingga mendapatkan keputusankeputusan untuk mengawasi permasalahan yang dihadapi.

\section{Saran}

Berdasarkan hasil penelitian yang dilakukan maka peneliti memberikan beberapa saran sebagai berikut:

1. Anggota Dewan Perwakilan Rakyat Daerah Kabupaten Bengkulu Tengah menjalankan fungsi pengawasan lebih baik lagi dalam artian dapat merespon masukan masyarakat, tingkatkan informasi-informasi terhadap penyimpangan yang ada.

2. Dewan Perwakilan Rakyat Daerah (DPRD) akan tugasnya dalam mengembangkan Daerah yang menuju Kabupaten yang lebih baik lagi.

3. Dewan Perwakilan Rakyat Daerah (DPRD) pada hakikatnya lebih cepat tanggap sebelum banyak komentar ataupun keluhan dari masyarakat.

4. Dewan Perwakilan Rakyat Daerah (DPRD) Kabupaten Bengkulu Tengah untuk melakukan perbaikan kinerja Pemerintah Daerah untuk membawa Pemerintah Daerah lebih baik lagi.

\section{DAFTAR PUSTAKA}

M Suyanto .2004 Aplikasi Desain Grafis Untuk Periklanan Dilengkapi Sampul Iklan Terbaik Kelas Dunia . Yogyakarta, Andi. 
Mulyana.2001. Komunikasi Organisasi, Cetakan Kedua. Bandung.Remaja Rosdakarya.

Mulyana, Dedy. 2002. Komunikasi Efektif. Bandung Remaja Rosdakarya.

Madjaikara. 2004. Creatif Education Foundation

Nawawi. 2003. Moleong, 2002:179 Metote Penelitian Deskriptif

Peter, J. Paul dan Jerry C Olson. 2000. Jilid 1Edisi Keempat. Jakarta: Erlangga
Ruslan, Rosady.2002. Manajemen Humas dan Komunikasi Konsepsi dan Aplikasi, PT. Raja grafindo Persada, Jakarta

Sugiyono.2010. Metode Penelitian Kuantitatif Kualitatif \& RND. Bandung Alfab

Widyatama, Rendra. 2005. Pengantar Periklanan .Jakarta. Buana Samudra Indonesia. 